to be regretted that no competent hand has as yet undertaken the difficult but rarely engaging and worthy task of producing such a work. The more modest aim of this treatise is further stated by the author in these words: "Its purpose is to furnish within modest limits a simple and straightforward account of the great revivals and revival movements characteristic of our national religious history." And this aim it certainly reaches.

Beginning with a very general account of revivals in Scripture and history, our author proceeds to tell of the notable revivals, and their leaders, of American religious history. The great awakening of 1734-1749; the remarkable movement which culminated about 1800-1801, but went on periodically up to about 1825 ; the wonderful work of Nettleton and Finney; the great revival of 18571858; the work in the armies during the Civil War; and the movement led by Moody and Sankey about 1875 and on-all receive attention. Besides these larger movements and more notable men, numbers of others are mentioned and discussed. The treatment is sympathetic, and the subject itself is of such absorbing interest as to make up in large degree for the lacks of the book.

Altogether the work is a brief and compendious, connected and highly useful account of the religious revivals which have formed so important a feature of our country's history. The book should have a wide reading, especially among our preachers; and will serve as a transition work between the partial and sketchy treatises that have hitherto appeared, and that fuller and more complete and satisfying treatment for which we still must wait.

E. C. Dargan.

\title{
The Foundations of Education.
}

By Levi Seeley, Ph.D. Hinds \& Noble, New York.

This is an important and valuable contribution to the moral aspects of education. The author thinks that there 
are many subjects not touched upon in any school curriculum, or in any series of directions to school teachers which lie at the foundation of education, and he is entirely right on this subject. Surveying the educational world at large, on one side there is occasion for much solicitude, he thinks, regarding the moral conditions, though he is by no means pessimistic. His experience as professor of the Science and Art of Education in the New Jersey State Normal School has doubtless given him a point of view and practical experience from the teacher's standpoint which has contributed very greatly to the value of this work. The conception of the book is sound, viz., that education involves the moral development of the child as well as his intellectual growth. The teacher and parent, he says, are the chief factors in education. There are twenty-five chapters in this book, brief, clear and comprehensive. Some general idea of the scope of the writer may be gathered from the following topics: In chapter two he discusses the Motives for Becoming a Teacher; in chapter four, the Spirit of the School Room; in chapter six, the Basis of Promotion; chapter seven, Politeness; chapter nine, the Philosophy of School Discipline; chapter ten, Habit as an End in the School; chapter twelve, the Professional Spirit among Teachers; chapter thirteen, School Incentives ; and chapters twentyfour and twenty-five discuss the subject of Moral and Religious Instruction. This book may be commended to teachers as very helpful to them in many directions.

E. Y. MuLuins.

\section{The French Revolution.}

The Macmillan Co. New York. 1904.

This is the eighth volume of the Cambridge Modern History which was planned by the late Lord Acton and is appearing in two series, one predominantly religious, the other secular. This is the fourth volume to appear, the 